Journal of Tropical Ecology

http://journals.cambridge.org/TRO

Additional services for Journal of Tropical Ecology:

Email alerts: Click here

Subscriptions: Click here

Commercial reprints: Click here

Terms of use : $\underline{\text { Click here }}$

\title{
Effects of fire on above-ground forest biomass in the northern Brazilian Amazon
}

Flora da Silva Ramos Vieira Martins, Haron Abrahim Magalhães Xaud, João Roberto dos Santos and Lênio Soares Galvão

Journal of Tropical Ecology / Volume 28 / Issue 06 / November 2012, pp 591 - 601

DOI: 10.1017/S0266467412000636, Published online: 22 November 2012

Link to this article: http://journals.cambridge.org/abstract_S0266467412000636

How to cite this article:

Flora da Silva Ramos Vieira Martins, Haron Abrahim Magalhães Xaud, João Roberto dos Santos and Lênio Soares Galvão (2012). Effects of fire on above-ground forest biomass in the northern Brazilian Amazon. Journal of Tropical Ecology, 28, pp 591-601 doi:10.1017/S0266467412000636

Request Permissions : $\underline{\text { Click here }}$ 


\title{
Effects of fire on above-ground forest biomass in the northern Brazilian Amazon
}

\section{Flora da Silva Ramos Vieira Martins*,1, Haron Abrahim Magalhães Xaud*,†, João Roberto dos Santos* and Lênio Soares Galvão*}

\author{
* Instituto Nacional de Pesquisas Espaciais (INPE), Divisão de Sensoriamento Remoto (DSR), Av. dos Astronautas 1758, CEP: 12227-010, São José dos Campos (SP), \\ Brazil \\ $\dagger$ Empresa Brasileira de Pesquisa Agropecuária - Embrapa Roraima, BR-174, km 8, Distrito Industrial, CEP 69.301-970 - Boa Vista RR, Brazil \\ (Accepted 26 September 2012)
}

\begin{abstract}
Fires can significantly affect the structure, floristic composition and biomass content of tropical forests, which are not adapted to this disturbance. To assess the impact of understorey fires on above-ground biomass, this study was conducted in the northern Brazilian Amazon (Roraima state), where uncontrolled forest fires are recurrent. Fifty plots (0.25 ha each) distributed across five fire disturbance classes were inventoried. Losses in biomass stocks were significant $(-57 \%$ and $-63 \%)$ for forests that suffered from recurrent fires and progressively occurred until some point between 3 and $7 \mathrm{y}$ after the last fire, as deduced from previous studies. Twelve years after a fire event, biomass stocks were reconstituted, although differences in the floristic composition were associated with greater fire severity, particularly driven by the dominance of the Cecropia spp. In thrice-burned forests, live biomass reached levels of secondary forests of the same region. For large trees ( $>50 \mathrm{~cm} \mathrm{dbh}$ ), the reduction $(-54 \%)$ in biomass was significant in thrice-burned areas. These findings highlight the threat that fires represent for tropical rain forests and emphasise the need for long-term surveys in order to distinguish between the effects of fire severity, fire frequency and time-since-fire artefact.
\end{abstract}

Key Words: above-ground biomass, Amazon, carbon emissions, forest fire, tropical rain forest

\section{INTRODUCTION}

Fire occurrence generally increases after large-scale droughts in the Amazon (Alencar et al. 2006, 2011; Aragão et al. 2007, Bush et al. 2008, Yang et al. 2011). In 1997-1998, the region suffered from the influence of the El Niño-Southern Oscillation (ENSO), which contributed to one of the most important mega-fires in the world with 3.9 million ha of burned forests and up to $0.329 \mathrm{Pg}$ of biomass loss (Alencar et al. 2006). In the state of Roraima (northern Amazon), up to 1.4 million ha of primary forest were affected (Barbosa \& Fearnside 1999), which highlights the prominence of fires as a threat to these forests that should not normally burn (Cochrane \& Laurance 2002).

Uncontrolled fire incidents results in a wide diversity of ecological effects (Bowman et al. 2009), altering forest structure and floristic composition. Amazonian studies have demonstrated the higher mortality of smalldiameter trees in recently burned areas (Barlow et al.

\footnotetext{
${ }^{1}$ Corresponding author. Email: flora@florestal.eng.br
}

2003, Cochrane \& Schulze 1999), whereas an increase in mortality of larger trees $(\geq 50 \mathrm{~cm} \mathrm{dbh})$ has been reported 1-3 y after a fire (Barlow et al. 2003). A positive relationship was found between tree mortality and char height, which can be used as a proxy of fire intensity (Balch et al. 2011, Barlow et al. 2003).

Fire can dramatically reduce living biomass in tropical forests (Haugaasen et al. 2003, Slik et al. 2008), even to the same degree as logging activities (Gerwing 2002). In Amazonian forests, Cochrane \& Schulze (1999) estimated average biomass losses of $80 \%, 50 \%$ and $10 \%$ in heavily, moderately and lightly burned areas, respectively. Three years after the fire, the biomass had recovered to $49 \%$ of that of a neighbouring unburned forest and the loss of $107 \mathrm{Mg} \mathrm{ha}^{-1}$ was attributed to the delay in mortality of trees $\geq 50 \mathrm{~cm}$ in stem diameter (Barlow et al. 2003). Balch et al. (2011) reported losses of $32 \%$ and $21 \%$ with respect to the initial above-ground live biomass in once- and thrice-burned forests, respectively, with trees $<30 \mathrm{~cm}$ dbh significantly contributing to the total dead biomass. Thus, fire may be a critical factor for determining carbon balance in tropical forests (Balch et al. 2008, Zarin et al. 2005). 


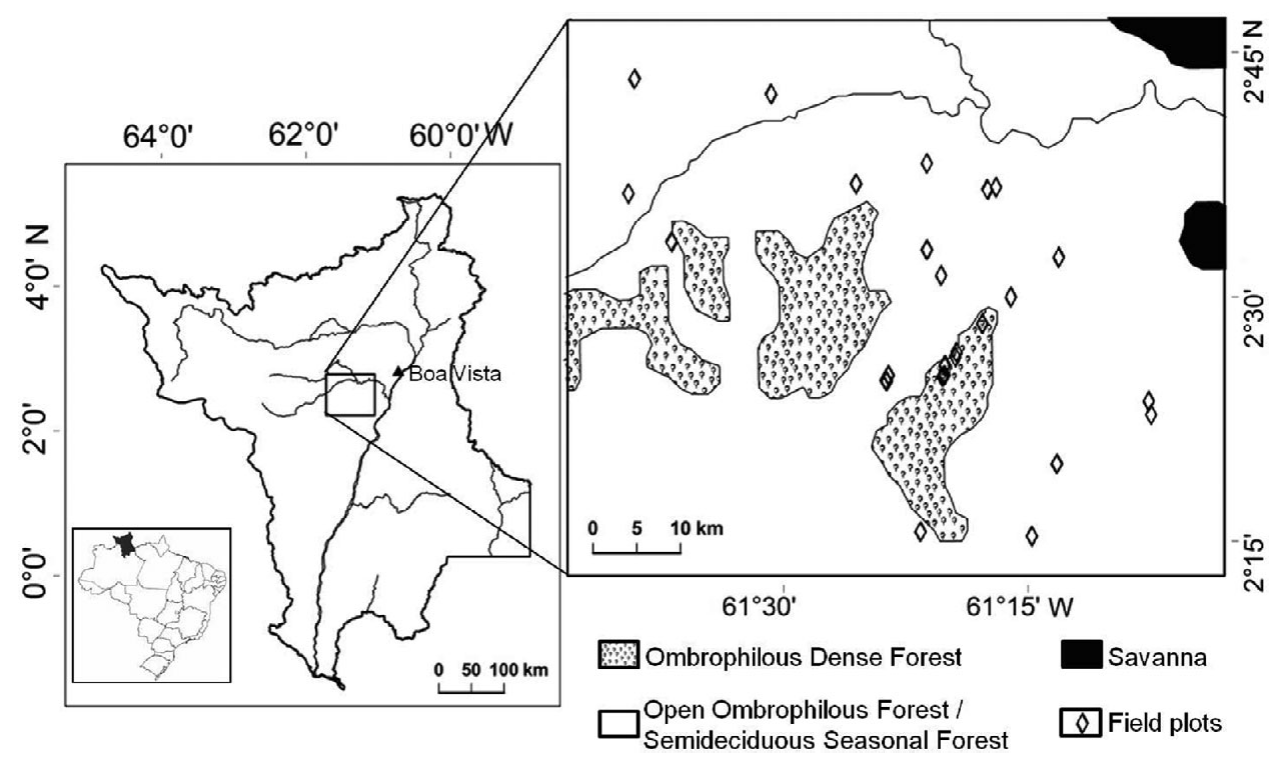

Figure 1. Location of the study area in northern Brazilian Amazon (state of Roraima) and of the sample plots used in data analysis. The 50 inventoried plots are not all distinguishable due to their proximity.

Tree species composition may have a considerable impact on the response of a forest to fire, as the probability of mortality is species-dependent (Balch et al. 2011, Brando et al. 2012, Slik et al. 2010). Fire tends to favour species that can tolerate heat stress and to increase the abundance of pioneer species (Barlow \& Peres 2008, Slik et al. 2010), at least in the short term (Cochrane \& Schulze 1999).

Ecosystems can normally recover from disturbances. However, frequent and severe fires can offset this balance. As a result, the ecosystem may lose the ability to recover, which could lead to its collapse with the loss of their major ecological functions. We hypothesize that fire disturbances of increasing frequency and severity, associated with shorter recovery times, may lead to declines in biomass and in species diversity. In this study, we examined the impact of single and repeated forest fires of different intensities on the above-ground live biomass.

\section{STUDY SITE}

This study was conducted in the Apiaú and Roxinho region in the central part of the state of Roraima, northern Brazilian Amazon (Figure 1). This region contains many rural land grants concentrated along the roads. Fires, which occur more frequently during the dry season, have historically been used for forest conversion and pasture maintenance, occasionally causing accidental fires in primary forests. Thus, in the study area, these fires are mainly understorey fires that escape from neighbouring pastures and reach the forest. The region was identified as the centre of the Great Fire of Roraima (Fearnside et al. 2007), which occurred in 1998 and was strongly influenced by ENSO.

The average annual precipitation is approximately $2000 \mathrm{~mm}$ (Barbosa \& Fearnside 1996), and the dry season extends from December to March. The topography is gently undulating to hilly predominantly 100-180 $\mathrm{m}$ asl (Fearnside et al. 2007). Soils are acidic and poor in nutrients (Barbosa \& Fearnside 1996). The natural vegetation mosaic is composed of tropical rain forests, tropical open forests and tropical semideciduous forests, which are located close to savannas (IBGE 1992).

\section{METHODS}

\section{Field sampling and data collection}

Field work was conducted in January and February of 2010. Plots $(25 \times 100 \mathrm{~m})$ were set up in unburned primary forests and across different classes of firedamaged primary forests (Table 1). The level of fire disturbance was defined in terms of the times of recurrence (fire frequency). The level of burn damage (severity) was also characterized for the areas that burned in 1998. Severity classes were defined based on historical information from remote-sensing data, locally obtained from landowner interviews and especially from results of IBAMA (1998) on post-fire mortality of trees, fuel quantity, scorch height and damage levels. Based on IBAMA (1998), 50\% of the area where plots are located was affected only at the understorey level (lightly burned), whereas $30 \%$ was affected by stronger fires that reached the understorey and canopy levels (heavily burned). The 
Table 1. Plot characterization and distribution across fire disturbance classes in northern Brazilian Amazon. $N$ is the number of plots.

\begin{tabular}{llrc}
\hline $\begin{array}{l}\text { Fire disturbances } \\
\text { classes (code) }\end{array}$ & $\begin{array}{l}\text { Year(s) of fire } \\
\text { occurrence(s) }\end{array}$ & $N$ & $\begin{array}{r}\text { Area } \\
\text { (ha) }\end{array}$ \\
\hline $\begin{array}{l}\text { Unburned forest (UF) } \\
\text { Once lightly burned forest (BF1L) }\end{array}$ & 1998 & 8 & 2 \\
Once heavily burned forest (BF1H) & 1998 & 8 & 2 \\
Twice-burned forest (BF2) & 1998,2003 & 10 & 2.5 \\
Thrice-burned forest (BF3) & $1998,2003,2007$ & 14 & 3.5 \\
Total & & 50 & 2.5 \\
\hline
\end{tabular}

rest of the area (20\%) was not affected by fire. In addition, field work observations on tree density and the general aspect of understorey supported the classification of the areas affected in 1998 in terms of severity. There were no signs of logging activities or history of other degradation type in the inventoried area.

Within each georeferenced plot, dbh and height were obtained for all individuals (trees, palms, bamboos and pseudostems of Phenakospermum guyannense with dbh $\geq 10 \mathrm{~cm}$. Tree heights were estimated visually by one of us (J. R. dos Santos) and then each tree height was modelled according to Gonçalves \& Santos (2008). The identification of morphospecies was performed from dendrological characteristics. Species nomenclature and family classification were adjusted to the Tropicos database (cite URL Tropicos.org 2012).

\section{Above-ground biomass estimation}

Five allometric equations were used to estimate individual above-ground living dry biomass (Table 2), hereafter simply called biomass. For tree species (other than Cecropia spp.), we compared estimates from the allometric equations developed by Brown et al. (1989) and Chave et al. (2005), which are frequently employed in the Amazon Basin. Because there was no significant difference between them (ANOVA; $\alpha=0.05$ ), we decided to use the biomass values resulting from the allometric equation presented by Chave et al. (2005).

Above-ground biomass (AGB) was defined as the cumulative tree biomass whereas the total above-ground biomass (TAGB) was defined as the sum of the biomass of all individual trees, palms and $P$. guyannense pseudostems
( $\mathrm{dbh} \geq 10 \mathrm{~cm})$. Bamboos, which occurred in just one plot, were not included in the estimation of TAGB. Carbon content of biomass was assumed to be $50 \%$ (Fearnside 1997).

\section{Analysis of fire impacts on forest above-ground live biomass, structure and diversity}

Comparisons of the mean AGB and TAGB among the five fire disturbance classes were based on one-way analyses of variance (ANOVA) after checking each treatment for normality with Shapiro-Wilk's test (Shapiro \& Wilk 1965) and for homoscedasticity with Bartlett's test (Snedecor \& Cochran 1989). The Tukey's multiple comparison test was then used to identify significant differences $(\alpha=0.05)$ among the groups. This method was also used to assess changes in the contributions of each diameter size class to AGB, with or without considering individuals of the Cecropia spp. It is important to note that differences in AGB and TAGB between unburned and burned forests are indicative of direct reductions by fire as well as delayed mortality. Biomass gains incorporate growth of surviving trees in addition to the establishment of new individuals.

Floristic composition across plots was compared based on the species and families with the highest contributions to AGB. Shannon's diversity index $\left(H^{\prime}\right)$ and the importance value index (IVI), determined only for tree species, were assessed in relation to AGB. Finally, a principal coordinate analysis (PCO) was performed using the Bray-Curtis similarity measure and species abundance in order to identify floristic composition gradients within the classes.

\section{RESULTS}

\section{General characteristics}

A total of 5593 individuals were measured across all plots (12.5 ha). The sample was composed of 177 species ( 83 identified only to the generic level and 19 unidentified) distributed across 122 genera and 53 families. For the unburned forest plots, the mean $( \pm \mathrm{SD})$ density of trees, mean $( \pm \mathrm{SD})$ dbh and mean $( \pm \mathrm{SD})$ basal area were $310 \pm$

Table 2. Allometric equations used to estimate above-ground live biomass (Y) per individual (kg) in each species group in northern Brazilian Amazon. $\rho$ is the specific gravity $\left(\mathrm{g} \mathrm{cm}^{-3}\right), \mathrm{Ht}$ is total height $(\mathrm{m})$ and dbh is diameter at breast height $(\mathrm{cm})$.

\begin{tabular}{|c|c|c|c|}
\hline Species group & Allometric equation & Equation source & $\rho$ \\
\hline Generic trees & $\ln \mathrm{Y}=-2.98+\ln \left(\rho \times \mathrm{dbh}^{2} \times \mathrm{Ht}\right)$ & Chave et al. (2005) & 0.69 (Fearnside 1997) \\
\hline Generic trees & $\ln \mathrm{Y}=-3.11+\left(0.97 \times \ln \left(\mathrm{dbh}^{2} \times \mathrm{Ht}\right)\right)$ & Brown et al. (1989) & \\
\hline Urticaceae (Cecropia spp.) & $\ln Y=-2.51+2.43 \times \ln (\mathrm{dbh})$ & Nelson et al. (1999) & \\
\hline Palms & $\ln \mathrm{Y}=-6.38-0.88 \ln \left(1 / \mathrm{dbh}^{2}\right)+2.15 \ln (\mathrm{Ht})$ & Saldarriaga et al. (1988) & \\
\hline P.guyannense (pseudostems) & $\ln Y=-2.98+\ln \left(\rho \times \mathrm{dbh}^{2} \times \mathrm{Ht}\right)$ & Chave et al. (2005) & 0.31 (Baker et al. 2004) \\
\hline
\end{tabular}




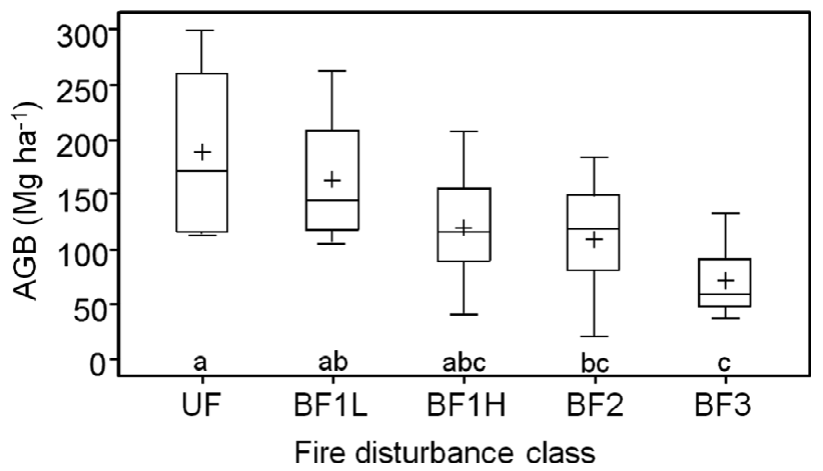

Figure 2. Boxplots showing the gradual effect of fire frequency and severity on mean above-ground living biomass (AGB in $\mathrm{Mg} \mathrm{ha}^{-1}$ ) in northern Brazilian Amazon. UF = unburned forest; $\mathrm{BF} 1 \mathrm{~L}=$ once lightly burned forest; $\mathrm{BF} 1 \mathrm{H}=$ once heavily burned forest; $\mathrm{BF} 2=$ twiceburned forest and BF3 = thrice-burned forest. Different letters $(\mathrm{a}, \mathrm{b}$ and c) associated with the fire disturbance classes indicate significant differences according to the Tukey's test $(\alpha=0.05)$.

28 ind. ha ${ }^{-1}, 23 \pm 15 \mathrm{~cm}$ and $18 \pm 5 \mathrm{~m}^{2} \mathrm{ha}^{-1}$, respectively. A Shannon index $\left(H^{\prime}\right)$ of 4.02 was obtained for the UF plots considering only the tree species.

\section{Effects of fire on above-ground live biomass}

Significant differences in AGB were found between the fire disturbance classes, indicating a gradual effect of successive fires on biomass (Figure 2). The mean AGB ranged from $70 \pm 32 \mathrm{Mg} \mathrm{ha}^{-1}$ in thrice-burned forest (BF3) to $188 \pm 78 \mathrm{Mg} \mathrm{ha}^{-1}$ in unburned forest (UF). According to the Tukey's test, the mean AGB was not significantly different among the UF, the once lightly (BF1L) $\left(163 \pm 57 \mathrm{Mg} \mathrm{ha}^{-1}\right)$ and the once heavily (BF1H) $\left(119 \pm 52 \mathrm{Mg} \mathrm{ha}^{-1}\right)$ burned forest plots. UF plots had significantly higher levels of AGB than twice- (BF2) $\left(108 \pm 48 \mathrm{Mg} \mathrm{ha}^{-1}\right)$ and thrice- (BF3) $\left(70 \pm 32 \mathrm{Mg} \mathrm{ha}^{-1}\right)$ burned forest plots, which showed mean reductions of biomass stocks of $57 \%$ and $63 \%$, respectively.

The loss of biomass between UF and BF1H (37\%) was about three times greater than the difference between UF and BF1L (13\%). BF1H presented an intermediate degree of degradation, as its mean biomass was not significantly different from either the two less-disturbed classes (UF and $\mathrm{BF} 1 \mathrm{~L})$ or the most disturbed classes (BF2 and BF3). The presence or absence of Cecropia spp. from the analysis did not change the results.

In UF plots, carbon storage in the living AGB was estimated at $94 \mathrm{Mg} \mathrm{C} \mathrm{ha}^{-1}$. After a single fire event, this stock was reduced to $81 \mathrm{Mg} \mathrm{C}^{-1}$ in BF1L and to $59 \mathrm{Mg} \mathrm{C}^{-1}$ in $\mathrm{BF} 1 \mathrm{H}$. The latter value is close to the $54 \mathrm{Mg} \mathrm{C}$ ha $^{-1}$ found in BF2. In BF3, $35 \mathrm{Mg} \mathrm{C} \mathrm{ha}^{-1}$ remained stored in living AGB, indicating a difference of $59 \mathrm{Mg} \mathrm{C}$ ha $^{-1}$ of carbon in relation to UF plots.

The mean contribution of palms and P. guyannense pseudostems to the TAGB reached approximately 5\%
Table 3. Variation in biomass values for fire disturbance classes $(\mathrm{UF}=$ unburned forest; $\mathrm{BF} 1 \mathrm{~L}=$ once lightly burned forest; $\mathrm{BF} 1 \mathrm{H}=$ once heavily burned forest; $\mathrm{BF} 2=$ twice-burned forest and $\mathrm{BF} 3=$ thrice-burned forest) in northern Brazilian Amazon. AGB $=$ above-ground live biomass (mean \pm $\mathrm{SD})$; $\mathrm{TAGB}=$ total above-ground live biomass (mean $\pm \mathrm{SD}$ ). The values of AGB and TAGB were not significantly different, considering each class, according to the Tukey's test $(\alpha=0.05)$.

\begin{tabular}{lll}
\hline Class & AGB $\left(\mathrm{Mg} \mathrm{ha}^{-1}\right)$ & TAGB $\left(\mathrm{Mg} \mathrm{ha}^{-1}\right)$ \\
\hline UF & $188 \pm 78$ & $195 \pm 74$ \\
BF1L & $163 \pm 57$ & $171 \pm 58$ \\
BF1H & $119 \pm 52$ & $127 \pm 50$ \\
BF2 & $108 \pm 48$ & $111 \pm 48$ \\
BF3 & $70 \pm 32$ & $74 \pm 33$ \\
\hline
\end{tabular}

(Table 3) considering the five classes, while the palms alone contributed $3.2 \%\left(4.2 \mathrm{Mg} \mathrm{ha}^{-1}\right)$. The low biomass contributions of palms and $P$. guyannense explained the similar results of the ANOVA and Tukey's test between AGB and TAGB (Table 3). In UF plots, the mean contribution of palms to TAGB was estimated at $6.81 \pm$ $6.94 \mathrm{Mg} \mathrm{ha}^{-1}$ or $3 \%$. Palm contributions to TAGB were substantial in UF and BF1L (4\%) plots, whereas $P$. guyannense pseudostems were most important in $\mathrm{BF} 1 \mathrm{H}$ plots $(4 \%)$.

\section{Effects of fire on biomass in relation to tree size distribution}

The distribution of mean AGB values in dbh sizes $\leq 50 \mathrm{~cm}$ did not show a clear pattern with respect to fire disturbance classes, except for the BF3, in which the mean AGB decreased when compared with the other ones (Figure 3a). However, mean AGB was significantly lower in UF3 than in UF or BF1L. For the dbh class greater than $50 \mathrm{~cm}$, the AGB differences were more evident and progressively decreased as the level of fire disturbance increased (Figure 3a). However, the only significant difference was observed between UF and BF3 plots. For these large trees, AGB from the BF1L to BF3 fire disturbance classes was reduced by $21 \%, 45 \%, 50 \%$ and $54 \%$ relatively to the UF. We also noted that the mean contribution of $\leq 50 \mathrm{~cm}$ dbh trees was similar to that of $>50 \mathrm{~cm}$ dbh trees in unburned plots. In these plots, differences in tree density of small (293 ind. ha ${ }^{-1}$ ) and large (17 ind. ha ${ }^{-1}$ ) trees highlighted the major contributions made by a few large trees to the AGB in primary undisturbed forests. The only gain in biomass observed in burned forests, in relation to UF, occurred in the BF1L among the $<50 \mathrm{~cm}$ dbh trees.

Because the individuals of Cecropia spp. (pioneer species that are common in burned areas) had generally less than $30 \mathrm{~cm}$ in diameter, the removal of this genus only altered the biomass in the smaller size classes (Figure 3b). For example, in the fire disturbance classes $\mathrm{BF} 1 \mathrm{H}, \mathrm{BF} 2$ and 

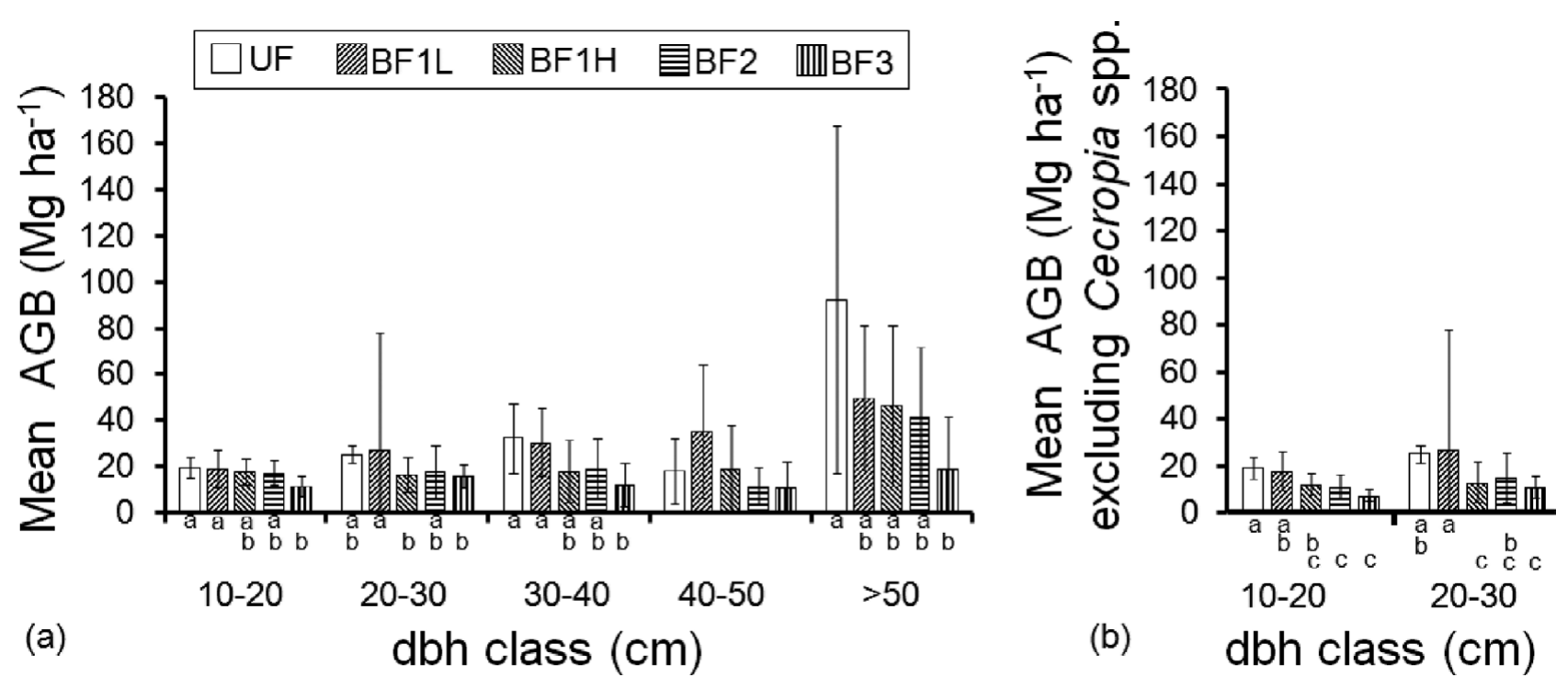

Figure 3. Fire effects on the above-ground biomass content by tree size classes in northern Brazilian Amazon. Mean values considering all tree species, merging large ( $>50 \mathrm{dbh} \mathrm{cm}$ ) individuals (a) and considering only small individuals ( $\mathrm{dhb} \leq 30 \mathrm{~cm}$ ) other than the Cecropia spp. (b), by fire disturbance classes: $\mathrm{UF}=$ unburned forest; $\mathrm{BF} 1 \mathrm{~L}=$ once lightly burned forest; $\mathrm{BF} 1 \mathrm{H}=$ once heavily burned forest; $\mathrm{BF} 2=$ twice-burned forest and BF $3=$ thrice-burned forest. Different letters (a, b and c) associated with the fire disturbance classes indicate significant differences by dbh class according to Tukey's test $(\alpha=0.05)$. For the $40-50 \mathrm{dbh}$ class, the data did not fulfil the requirements for ANOVA.

$\mathrm{BF} 3$, removal of these species from the $10-20-\mathrm{cm} \mathrm{dbh}$ class resulted in biomass losses of $32 \%, 36 \%$ and $34 \%$, respectively. As a result, differences in biomass between these heavily disturbed forests and unburned or lightly burned forests were accentuated.

\section{Species contributions to biomass}

For the five species with the highest contributions to AGB, mean dbh generally decreased and mean density increased with fire disturbance (Appendix 1). These trends were partially driven by individuals of Cecropia leucocoma Miq., which made notable contributions to AGB in the $\mathrm{BF} 1 \mathrm{H}$ as well as in the more heavily burned classes, also with increasing IVI. Similar results were found for Pouteria sp., whereas Protium sp. made major contributions to AGB in the UF, BF1L, BF1H and BF2 plots (approximately 9\%) and it was not an important species in BF3 plots. These selected tree species were mainly classified as non-pioneer species, except in the thrice-burned forest. Vochysia sp. and Manilkara huberi (Ducke) A. Chev., two species of economic interest, had the highest AGB values in BF1L.

Concerning palm species, Oenocarpus bacaba Mart. was present with highest abundance in UF and BF1L plots, while Maximiliana martiana $\mathrm{H}$. Karst. was more frequent in BF2 and BF3 plots. However, Maximiliana martiana made the highest contribution to biomass among all palms in every fire disturbance class except BF1L.

The contribution of Leguminosae to AGB decreased with increasing fire disturbance and reached 5\% in BF3 (Appendix 1). The contribution of Vochysiaceae showed values close to $1 \%$ in $\mathrm{BF} 1 \mathrm{H}, \mathrm{BF} 2$ and $\mathrm{BF} 3$. The Sapotaceae made high contributions to AGB in all classes and no clear trend in relation to fire damage was detected. The Burseraceae, another predominant family, contributed to AGB up to BF3, where the contribution fell to $4 \%$. The Apocynaceae made a substantial contribution to AGB in BF $1 \mathrm{H}$ plots $(16 \%)$ but only accounted for $2 \%$ in the other classes. The AGB contribution of Urticaceae, represented by two species of Cecropia, increased with fire damage. The contribution of Sapindaceae to AGB increased slightly in the most damaged plots (Appendix 1).

\section{Relationships between plant diversity, biomass and fire disturbance}

The highest mean diversity of tree species $\left(H^{\prime}\right)$ was found in the UF class (4.02). BF1L and BF1H plots, which only differed in fire severity, exhibited the greatest difference in diversity between two successive classes (3.95 and 3.14 , respectively, or $-22 \%)$. A significant reduction in diversity was observed in $\mathrm{BF} 1 \mathrm{H}$ in relation to UF plots $(-28 \%)$, even $12 \mathrm{y}$ after the fire. Conversely, BF1L plots showed only minor reductions in diversity after the same recovery time. Similar and lower values of $H^{\prime}$ were found for BF2 and BF3 (2.90 and 2.89, respectively).

$H^{\prime}$ was positively related to AGB (Figure 4). An outlier plot was removed from the regression (in $\mathrm{BF} 1 \mathrm{H}$, $\mathrm{AGB}=207 \mathrm{Mg} \mathrm{ha}^{-1} ; H^{\prime}=1.81$ ) because the abnormal biomass value could be mostly explained by two trees. For the $\mathrm{BF} 1 \mathrm{H}$ and $\mathrm{BF} 2$, there was a positive relationship between AGB and $H^{\prime}$. For the UF, BF 1 L and BF 3 classes, no 


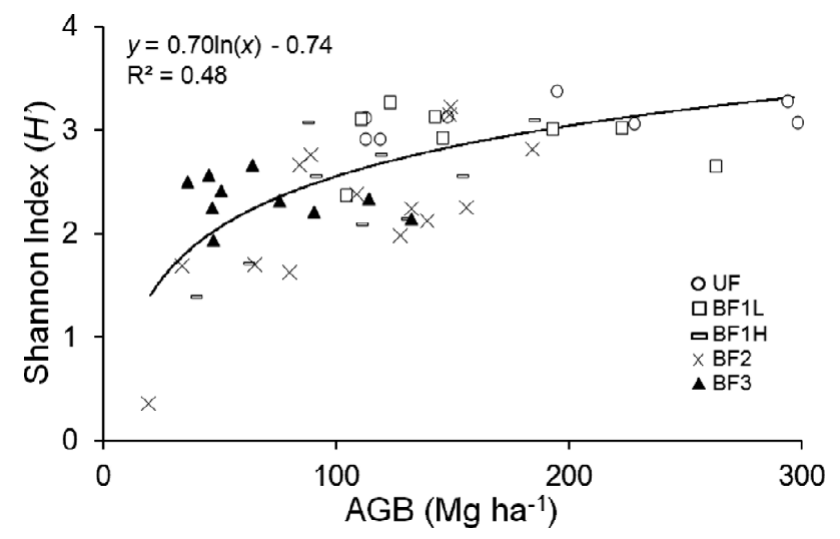

Figure 4. Logarithmic relationship between AGB and $H^{\prime}$ for the full set of plots inventoried in the northern Brazilian Amazon and their relationships with each fire disturbance class (UF = unburned forest; $\mathrm{BF} 1 \mathrm{~L}=$ once lightly burned forest; $\mathrm{BF} 1 \mathrm{H}=$ once heavily burned forest; $\mathrm{BF} 2=$ twice-burned forest and BF3 = thrice-burned forest).

significant relationships were found because the diversity was constant across the biomass range.

The first two ordination axes of the PCO explained $21.1 \%$ and $13.4 \%$ of the total variability of the floristic composition (Figure 5). The plots were gradually distributed along the first axis according to the firedamage classes, with a clear discrimination between UF and BF 3 plots. The second axis showed a detachment of a set of plots mainly associated with the BF1H class.

\section{DISCUSSION}

\section{Above-ground biomass content of unburned primary forests in Apiaú region}

The mean AGB recorded in unburned primary forests, $188 \pm 78 \mathrm{Mg} \mathrm{ha}^{-1}$, was consistent with results of previous studies in the same region by Xaud (1998) and Barbosa et al. (2010). Our results agreed with earlier findings showing that these Amazon forests located close to savannas had lower biomass than the dense rain forest of the central Amazon (Malhi et al. 2006, Saatchi et al. 2007). In these tropical forests, the effect of large trees on biomass was exemplified by individuals of Dinizia excelsa, which strongly increased the AGB in the UF and BF1H classes. Dinizia excelsa is an emergent species that occurs at low densities and has a high specific gravity (EMBRAPA 2004).

\section{Losses and post-fire biomass recovery}

As expected, our results showed a gradual reduction in biomass stocks after more frequent/severe fires on the studied time scale. By comparing BF1L and BF1H, the impact of fire severity to produce higher reductions in biomass was demonstrated, as also reported by Gerwing (2002). Thus, the dynamics of biomass recovery was reduced by fire severity.

The range of AGB values in the BF3 class (36-114 $\mathrm{Mg} \mathrm{ha}^{-1}$ ) revealed that some plots that experimented recurrent fire events reached similar levels of live aboveground biomass to those of secondary forests estimated in the same region by Xaud (1998) and Araújo (1999) with values ranging from 33 to $57 \mathrm{Mg} \mathrm{ha}^{-1}$ and from 14 to $79 \mathrm{Mg} \mathrm{ha}^{-1}$, respectively. The gain in biomass observed for the BF1L in relation to UF class, regarding $\leq 50 \mathrm{~cm}$ $\mathrm{dbh}$ trees, showed forest recovery and establishment of intermediate-diameter and non-pioneer trees after $12 \mathrm{y}$ from the fire. For the dbh class $>50 \mathrm{~cm}$, differences in AGB were more pronounced revealing the impact of fire on the AGB of large trees.

Figure 6 summarizes some of the major post-fire biomass studies performed in the Amazon basin and

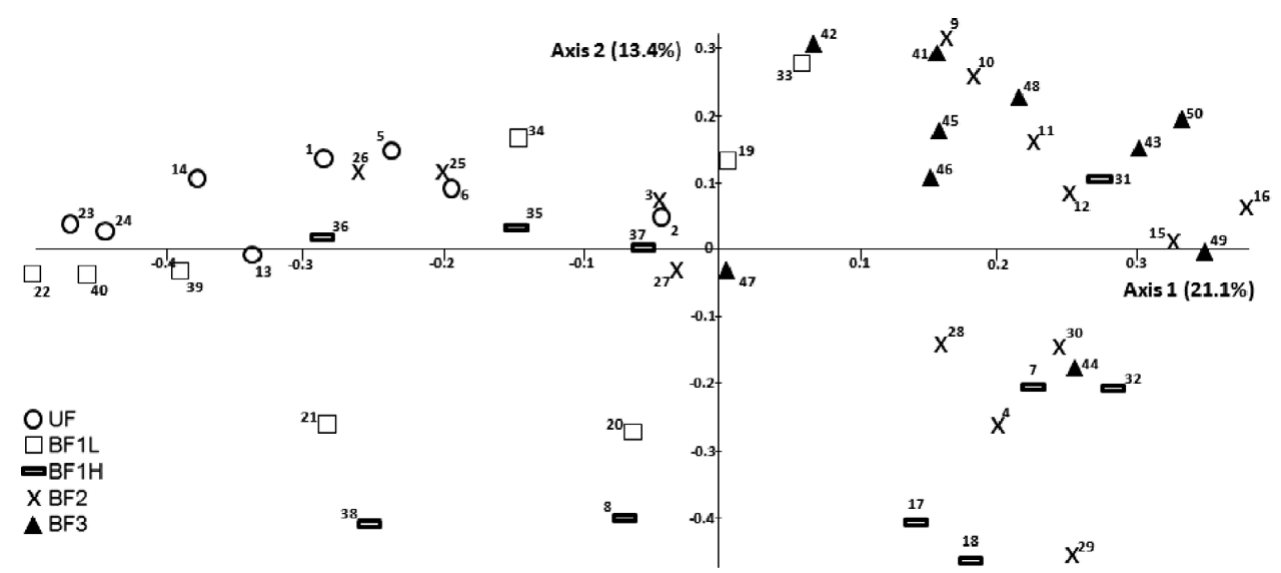

Figure 5. Scatter plot showing the first and second axis of the principal coordinate analysis (PCO) considering the 50 inventoried forest plots in northern Brazilian Amazon, based on Bray-Curtis similarity measure and floristic abundance data. UF $=$ unburned forest; BF1L $=$ once lightly burned forest; $\mathrm{BF} 1 \mathrm{H}=$ once heavily burned forest; $\mathrm{BF} 2=$ twice-burned forest and $\mathrm{BF} 3=$ thrice-burned forest. 


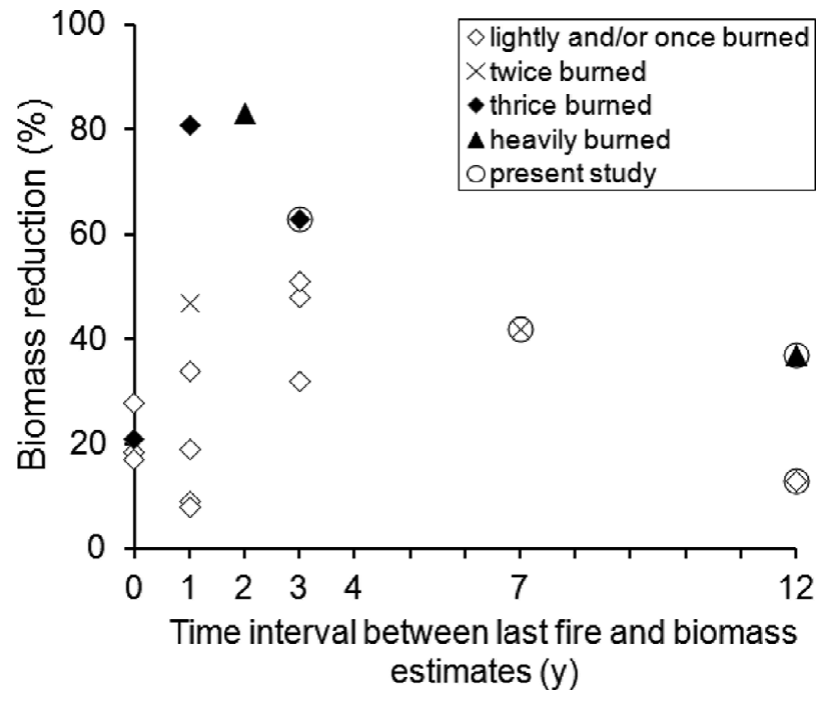

Figure 6. Synthesis of results in terms of living above-ground biomass reduction (or difference) with respect to the time interval between the last fire and AGB data collection (y) based on nine studies in the Brazilian Amazon (Balch et al. 2011, Barbosa \& Fearnside 1999, Barlow et al. 2003, Cochrane et al. 1999, Fearnside et al. 2001, 2007; Gerwing 2002, Graça et al. 1999, Haugaasen et al. 2003) as well as the present study.

illustrates the temporal dynamics of biomass levels after a fire event. Time intervals between fires, the number of fire occurrences, fire severity and remaining biomass estimates have been reported. The biomass estimates from the present study were associated with the longest postfire time interval $(12 \mathrm{y})$, complementing the results of the previous ones. The values formed a hump-shaped distribution, with an increase in biomass loss within the first $3 \mathrm{y}$ after the fire.

Previous studies reported a reduction in biomass of approximately $20 \%$ immediately after a fire (Balch et al. 2011, Fearnside et al. 2001, 2007; Graça et al. 1999), with an average loss of approximately $50 \% 3$ y later (Balch et al. 2011, Barlow et al. 2003, Gerwing 2002). This delay in biomass loss was likely the result of the higher resistance of large trees to fire, which expanded the mortality distribution over several years (Barlow et al. 2003). The loss of biomass was less severe 7 and 12 y after the fire, similar to the biomass values estimated immediately after the fire. Although the precise point at which biomass stops decreasing after a fire remains unclear, our analysis suggested that it may be between 3 and 7 y after the fire, assuming no additional disturbances. Twelve years after the fire occurrence, the biomass was not significantly different from the initial level, illustrating the resilience of these forests in term of biomass recovery, at least for areas burned only once.

Our results confirmed that forest resilience in terms of biomass depends on the fire history, which includes not only the elapsed time after the fire but also the fire frequency and severity (Numata et al. 2011). Both fire frequency and severity increased the loss of biomass and delayed its recovery. The exception was for the thriceburned forests in which biomass was measured less than $1 \mathrm{y}$ after the last fire, and because the intervals between the three fires were abnormally short (Balch et al. 2011). Thrice-burned and heavily burned forests, observed 1 and $2 \mathrm{y}$ after the last fire, respectively, had experienced the greatest loss of biomass. For these two cases, only one of the two critical variables (severity and frequency) was available.

\section{Relationships between biomass, diversity and fire}

The Shannon index $\left(H^{\prime}\right)$ of 4.02 obtained in our UF plots was slightly those obtained in the Roraima state by Alarcón \& Peixoto (2007), 4.66, or in the National Forest of Tapajós (Pará state), by Gonçalves \& Santos (2008), 4.22. In the central Amazon, high levels of diversity were found by Oliveira et al. (2008) $\left(H^{\prime}\right.$ of 5.1).

Tree diversity decreased with fire disturbance in the Amazon, as demonstrated by Barlow et al. (2003) and Cochrane \& Schulze (1999). In the case of BF1L, a postfire recovery time of $12 \mathrm{y}$ allowed tree diversity $\left(H^{\prime}\right)$ to return to initial levels with a floristic composition very similar to the unburned forests, as shown by our PCO analysis. However, severely, recently and/or recurrently burned areas (BF1H, BF2 and BF3) showed lower diversity than lightly burned or unburned forests (BF1L, UF). The difference between $H^{\prime}$ values of $\mathrm{BF} 1 \mathrm{H}$ and $\mathrm{BF} 1 \mathrm{~L}$ likely stems from the fact that this type of disturbance favoured the regeneration of $P$. guyannense pseudostems. This was confirmed by our PCO results, where the second axis clearly discriminated plots with high pseudostem densities, reaching 237 pseudostems ha $^{-1}$ in plot 8 . Thus, fire severity seems to be one of the most important factors for determining post-fire forest resilience, at least in terms of diversity.

In cases of increased fire recurrence and decreased recovery time (BF2), the positive relation between biomass and diversity illustrates the similar responses of the two proxies to fire disturbance. In plots exhibiting increased fire recurrence and reduced post-fire intervals (BF3), no relationship between biomass and diversity was observed. We hypothesize that in these recurrently disturbed forests, the time after each fire was not sufficient for the biomass to recover, as large tree mortality continues for several years after a fire event (Barlow et al. 2003). BF3 also had the lowest mean values for biomass but not for diversity. This pattern suggests that the characteristics of BF3 fires favoured the installation of evenly distributed pioneer species and that these changes in vegetation composition did not alter the Shannon diversity index. Such recurrent disturbances thereby 
negated the relationship between biomass and diversity. As neither biomass nor diversity values were estimated before the second or third fires, and as no long-term studies on post-fire biomass dynamics have been performed in this region, we were not able to dissociate the effects of fire recurrence, severity and elapsed time after fire on biomass and vegetation diversity.

When pioneer individuals of Cecropia spp. were removed from the analysis of tree size distribution, differences in AGB and the significance of these differences were enhanced only for small trees. This result can be explained by the observation that Cecropia spp. diameters were always $<40 \mathrm{~cm}$ in our sample. Indeed, Cochrane \& Schulze (1999) and Barlow \& Peres (2008) described the dense post-fire establishment of pioneer species, which compensates for the loss of Amazonian primary forest trees.

Despite a few reports of low mortality of Cecropia spp. after low or mild fire severity (d'Oliveira et al. 2011, Uhl et al. 1981), Barlow \& Peres (2008) found that the density of these pioneer species and their contributions to AGB decreased relative to other species after recurrent fires. In other words, these pioneers were more sensitive to fire recurrence. However, we found that pioneer IVI, density and contributions to AGB increased in sites where fires have occurred two or three times since 1998, especially for Cecropia spp. and Jacaranda copaia (Aubl.) D. Don. Except for lightly burned forests, Cecropia spp. made the highest contributions to AGB 3, 7 and $12 \mathrm{y}$ after the fire incident. Cochrane \& Schulze (1999) also reported an increase in pioneer density with increasing fire intensity and frequency. Moreover, not all individuals of Cecropia spp. in these forests were recently established, as their mean diameter was higher in the most disturbed plots. Therefore, the sensitivity of pioneer species to fire recurrence does not necessarily modify the vegetation structure through middle-term reductions in biomass or density contributions of such species, because nonpioneer species are progressively excluded from forest as fires occur. Fire recurrence might thus favour pioneer species renewal. The time elapsed between or after fires must be considered as a key factor in determining the biomass contribution patterns of pioneer species.

To some extent, our results agreed with those of Balch et al. (2011), who found that Protium guianense and Vochysia vismiifolia had high fire-induced mortality rates. Indeed, the biomass contribution of Protium sp. decreased with increasing fire frequency and for Vochysia sp. this contribution was the highest where the forest was only lightly burned (BF1L). The latter species was also recorded in UF plots. Pouteria spp. showed similar behaviours in the two studies, as its fire-induced mortality rate was low in Balch et al. (2011) and its biomass contribution increased with fire incidence. Fire-induced tree mortality may be influenced not only by cambium insulation but also by species traits that reduce the indirect effects of fire (Brando et al. 2012).

In the same region, Fearnside et al. (2007) found a palm biomass reduction of $79 \%\left(2.09 \mathrm{Mg} \mathrm{ha}^{-1}\right.$ to $0.44 \mathrm{Mg} \mathrm{ha}^{-1}$ ) immediately after a fire event. Less severe reductions were found in the present study $(-65 \%$ in BF2, $-56 \%$ in $\mathrm{BF} 1 \mathrm{H}$ and $-52 \%$ in $\mathrm{BF} 3)$. Both results illustrate the major impact of fire on palm species, which represent less than $50 \%$ of the initial biomass, even $12 \mathrm{y}$ after a fire. These studies showed greater reductions in palm biomass compared with results by Graça et al. (1999) in open forests ( 8.6 to $7.1 \mathrm{Mg} \mathrm{ha}^{-1}$ or $17 \%$ ), or by Fearnside et al. (2001), in palms of central Amazon (1.3 to $1.1 \mathrm{Mg} \mathrm{ha}^{-1}$ or $15 \%)$.

\section{Carbon emissions}

Assessing changes in carbon stocks of the AGB is difficult because they are related not only to immediate fire impacts but also to delayed mortality and biomass recovery. Therefore, this balance integrates many sources and sinks and carbon estimates become more difficult with increasing time after a fire. However, for thrice-burned areas measured $3 \mathrm{y}$ after the last fire (maximum biomass losses according to findings of this work), we expected more precise estimations of carbon losses.

The need for long-term, precise surveys of burned sites in the Amazon is immediate, particularly given the present and future fire scenarios for the region. According to Cochrane \& Barber (2009), the future fire regime will be a product of climate change and human land practices. For example, the predicted warmer and drier climate (Salazar et al. 2007) may result in an increase in hazards related to natural fire ignition and propagation. Fires may therefore become more frequent and intense, increasing the vulnerability of the forest and imparting high risks of biodiversity erosion and biomass loss.

In conclusion, the biomass stocks in the studied area were drastically affected by fire, and important shifts in tree size distribution and species contributions to biomass occurred after each additional fire event. Losses in biomass stocks were significant after fire recurrence. Twelve years after the fire, biomass stocks had recovered in once-burned forests, although differences in floristic composition were still observed in higher fire severity classes. For large trees $(>50 \mathrm{~cm} \mathrm{dbh})$, there was a notable reduction in biomass after one or two fire events, whereas this reduction was significant in thrice-burned areas. In terms of species contribution, we observed that Cecropia spp. dominated the biomass composition, even 12 y after a severe fire incident. Our results, in combination with those of previous studies, showed that forest recovery of biomass depends on fire history (e.g. elapsed time, 
fire frequency and severity) and that losses progressively occur until some point between 3 and $7 \mathrm{y}$ after the last fire, assuming no additional disturbances. Both fire frequency and severity exacerbated biomass losses and delayed biomass recovery. Overall, the present study confirms the high vulnerability of these tropical forests (located close to savannas) to fire. It remains difficult to distinguish between the effects of fire frequency, fire severity and time since last fire artefact on vegetation. Long-term surveys are therefore essential for assessing the diversity of ecological impacts of fire on Amazon forests.

\section{ACKNOWLEDGEMENTS}

We acknowledge Conselho Nacional de Desenvolvimento Científico e Tecnológico $(\mathrm{CNPq})$ for the research grants. We also received financial and logistic support from the Instituto Nacional de Pesquisas Espaciais (INPE) and Empresa Brasileira de Agropecuária (EMBRAPARoraima). Field work assistance was provided by rural crews from Apiaú and Sr. Erly Pedroso (parabotanist). We also thank DanielE. Silva for his helpful contributions. The authors are very grateful to the anonymous reviewers for the very useful suggestions.

\section{LITERATURE CITED}

ALARCÓN, J. G. S. \& PEIXOTO, A. L. 2007. Floristic composition and structure in one hectare of terra firme forest, Caracaraí, state of Roraima, Brazil. Boletim do Museu Paraense Emílio Goeldi. Ciências Naturais 2:33-60.

ALENCAR, A., NEPSTAD, D. \& DIAZ, M. C. V. 2006. Forest understory fire in the Brazilian Amazon in ENSO and non-ENSO years: area burned and committed carbon emissions. Earth Interactions 10:117.

ALENCAR, A., ASNER, G. P., KNAPP, D. \& ZARIN, D. 2011. Temporal variability of forest fires in eastern Amazonia. Ecological Applications 21:2397-2412.

ARAGÃO, L. E. O. C., MALHI, Y., ROMAN-CUESTA, R. M., SAATCHI, S., ANDERSON, L. O.\& SHIMABUKURO, Y. E. 2007. Spatial patterns and fire response of recent Amazonian droughts. Geophysical Research Letters 34:L07701.

ARAÚJO, L. S. 1999. Análise da cobertura vegetal e de biomassa em áreas de contato floresta/savana a partir de dados TM/LANDSAT e JERS-1. Instituto Nacional de Pesquisas Espaciais, São José dos Campos. 115 pp.

BAKER, T. R., PHILLIPS, O. L., MALHI, Y., ALMEIDA, S., ARROYO, L., DI FIORE, A., ERWIN, T., KILLEEN, T. J., LAURANCE, S. G., LAURANCE, W. F., LEWIS, S. L., LLOYD, J., MONTEAGUDO, A., NEILL, D. A., PATiÑO, S., PITMAN, N. C. A., SILVA, J. N. M. \& MARTINEZ, R. V. 2004. Variation in wood density determines spatial patterns in Amazonian forest biomass. Global Change Biology 10:545562.

BALCH, J. K., NEPSTAD, D. C., BRANDO, P. M., CURRAN, L. M., PORTELA, O., DE CARVALHO, O. \& LEFEBVRE, P. 2008. Negative fire feedback in a transitional forest of southeastern Amazonia. Global Change Biology 14:2276-2287.

BALCH, J. K., NEPSTAD, D. C., CURRAN, L. M., BRANDO, P. M., PORTELA, O., GUILHERME, P., REUNING-SCHERER, J. D. \& CARVALHO, O. 2011. Size, species, and fire behavior predict tree and liana mortality from experimental burns in the Brazilian Amazon. Forest Ecology and Management 261:68-77.

BARBOSA, R. I. \& FEARNSIDE, P. M. 1996. Carbon and nutrient flows in an Amazonian forest: fine litter production and composition at Apiaú, Roraima, Brazil. Tropical Ecology 37:115-125.

BARBOSA, R. I. \& FEARNSIDE, P. M. 1999. Incêndios na Amazônia brasileira: estimativa da emissão de gases do efeito estufa pela queima de diferentes ecossistemas de Roraima na passagem do evento "El Niño" (1197/98). Acta Amazônica 29:513-534.

BARBOSA, R. I., KEIZER, E. \& PINTO, F. 2010. Ecossistemas terrestres de Roraima: área e modelagem espacial da biomassa. Pp. 347-368 in Barbosa, R. I. \& Melo, V. F. (eds.) Roraima: homem, ambiente e ecologia. FEMACT, Boa Vista. 644 pp.

BARLOW, J. \& PERES, C. A. 2008. Fire-mediated dieback and compositional cascade in an Amazonian forest. Philosophical Transactions of the Royal Society of London, Series B, Biological Sciences 363:1787-1794.

BARLOW, J., PERES, C. A., LAGAN, B. O.\& HAUGAASEN, T. 2003. Large tree mortality and the decline of forest biomass following Amazonian wildfires. Ecology Letters 6:6-8.

BOWMAN, D. M. J. S., BALCH, J. K., ARTAXO, P., BOND, W. J., CARLSON, J. M., COCHRANE, M. A., D'ANTONIO, C. M., DEFRIES, R. S., DOYLE, J. C., HARRISON, S. P., JOHNSTON, F. H., KEELEY, J. E., KRAWCHUK, M. A., KULL, C. A., MARSTON, J. B., MORITZ, M. A., PRENTICE, I. C., ROOS, C. I., SCOTT, A. C., SWETNAM, T. W., VAN DER WERF, G. R. \& PYNE, S. J. 2009. Fire in the Earth system. Science 324:481-484.

BRANDO, P. M., NEPSTAD, D. C., BALCH, J. K., BOLKER, B. M., CHRISTMAN, M. C., COE, M. T. \& PUTZ, F. E. 2012. Fire-induced tree mortality in a neotropical forest: the roles of bark traits, tree size, wood density and fire behavior. Global Change Biology 18: 630-641.

BROWN, S., GILLESPIE, A. J. R. \& LUGO, A. E. 1989. Biomass estimation methods for tropical forests with applications to forest inventory data. Forest Science 35:881-902.

BUSH, M. B., SILMAN, M. R., MCMICHAEL, C. \& SAATCHI, S. 2008. Fire, climate change and biodiversity in Amazonia: a Late-Holocene perspective. Philosophical Transactions of the Royal Society of London. Series B, Biological Sciences 363:1795-1802.

CHAVE, J., ANDALO, C., BROWN, S., CAIRNS, M. A, CHAMBERS, J. Q., EAMUS, D., FÖLSTER, H., FROMARD, F., HIGUCHI, N., KIRA, T., LESCURE, J., NELSON, B. W., OGAWA, H., PUIG, H., RIÉRA, B. \& YAMAKURA, T. 2005. Tree allometry and improved estimation of carbon stocks and balance in tropical forests. Oecologia 145: 87-99.

COCHRANE, M. A. \& BARBER, C. P. 2009. Climate change, human land use and future fires in the Amazon. Global Change Biology 15:601612.

COCHRANE, M. A. \& LAURANCE, W. F. 2002. Fire as a large-scale edge effect in Amazonian forests. Journal of Tropical Ecology 18:311-325. 
COCHRANE, M. A. \& SCHULZE, M. D. 1999. Fire as a recurrent event in tropical forests of the eastern Amazon: effects on forest structure, biomass, and species composition. Biotropica 31:2-16.

COCHRANE, M. A., ALENCAR, A., SCHULZE, M., SOUZA, C., NEPSTAD, D. C., LEFEBVRE, P. \& DAVIDSON, E. 1999. Positive feedbacks in the fire dynamic of closed canopy tropical forests. Science 284:18321835.

D'OLIVEIRA, M. V. N., ALVARADO, E. C., SANTOS, J. C. \& CARVALHO, J. A. 2011. Forest natural regeneration and biomass production after slash and burn in a seasonally dry forest in the Southern Brazilian Amazon. Forest Ecology and Management 261:1490-1498.

EMBRAPA, 2004. Espécies arbóreas da Amazônia $N^{\circ}$ 6: Angelim-vermelho Dinizia excelsa. EMBRAPA Amazônia Oriental, Projeto Dendrogene, Belém, Pará. 1 pp.

FEARNSIDE, P. M. 1997. Wood density for estimating forest biomass in Brazilian Amazonia. Forest Ecology and Management 90: $59-87$.

FEARNSIDE, P. M., GRAÇA, P. M. L. A. \& RODRIGUES, F. J. A. 2001. Burning of Amazonian rainforests: burning efficiency and charcoal formation in forest cleared for cattle pasture near Manaus, Brazil. Forest Ecology and Management 146:115-128.

FEARNSIDE, P., BARBOSA, R. \& GRAÇA, P. M. L. A. 2007. Burning of secondary forest in Amazonia: biomass, burning efficiency and charcoal formation during land preparation for agriculture in Apiaú, Roraima, Brazil. Forest Ecology and Management 242:678-687.

GERWING, J. J. 2002. Degradation of forests through logging and fire in the eastern Brazilian Amazon. Forest Ecology and Management 157:131-141.

GONÇALVES, F. G. \& SANTOS, J. R. 2008. Floristic composition and structure of a sustainable forest management unit at Tapajos National Forest, Pará, Brazil. Acta Amazônica 38:229-244.

GRAÇA, P. M. L. A., FEARNSIDE, P. M. \& CERRI, C. C. 1999. Burning of Amazonian forest in Ariquemes, Rondônia, Brazil: biomass, charcoal formation and burning efficiency. Forest Ecology and Management 120:179-191.

HAUGAASEN, T., BARLOW, J. \& PERES, C. A. 2003. Surface wildfires in central Amazonia: short-term impact on forest structure and carbon loss. Forest Ecology and Management 179:321-331.

IBAMA (Instituto Brasileiro do Meio Ambiente e dos Recursos Naturais Renováveis) 1998. Avaliação rápida dos danos ambientais dos incêndios que atingiram as florestas de Roraima em 1998. Technical Report. IBAMA, Brasília. 87 pp.

IBGE (Instituto Brasileiro de Geografia e Estatística). 1992. Manual Técnico da Vegetação Brasileira. Manuais Técnicos em Geociências, n.1. IBGE, Rio de Janeiro. 92 pp.

MALHI, Y., WOOD, D., BAKER, T. R., WRIGHT, J., PHILLIPS, O. L., COCHRANE, T., MEIR, P., CHAVE, J., ALMEIDA, S., ARROYO, L., HIGUCHI, N., KILLEEN, T. J., LAURANCE, S. G., LAURANCE, W. F., LEWIS, S. L., MONTEAGUDO, A., NEILL, D. A., NUNEZ VARGAS, P., PITMAN, C. A., QUESADA, C. A., SALOMAO, R., SILVA, J. N. M. \& LEZAMA, A. T. 2006. The regional variation of aboveground live biomass in old-growth Amazonian forests. Global Change Biology 12:1107-1138.

NELSON, B. W., MESQUITA, R., PEREIRA, J. L. G., SOUZA, S. G. A., BATISTA, G. T. \& COUTO, L. B. 1999. Allometric regressions for improved estimate of secondary forest biomass in the central Amazon. Forest Ecology and Management 117:149-167.

NUMATA, I., COCHRANE, M. A. \& GALVÃO, L. S. 2011. Analyzing the impacts of frequency and severity of forest fire on the recovery of disturbed forest using Landsat time series and EO-1 Hyperion in the southern Brazilian Amazon. Earth Interactions 15:1-17.

OLIVEIRA, A. N. D., AMARAL, I. L. D., RAMOS, M. B. P., NOBRE, A. D., COUTO, L. B. \& SAHDO, R. M. 2008. Composição e diversidade florístico-estrutural de um hectare de floresta densa de terra firme na Amazônia Central, Amazonas, Brasil. Acta Amazonica 38:627-641.

SAATCHI, S. S., HOUGHTON, R. A., ALVALÁ, R. C. S., SOARES, J. V. \& YU, Y. 2007. Distribution of aboveground live biomass in the Amazon basin. Global Change Biology 13:816-837.

SALAZAR, L. F., NOBRE, C. A. \& OYAMA, M. D. 2007. Climatic change consequences on the biome distribution in tropical South America. Geophysical Research Letters 34:L09708.

SALDARRIAGA, J. G., WEST, D. C., THARP, M. \& UHL, C. 1988. Longterm chronosequence of forest succession in the upper Rio Negro of Colombia and Venezuela. Journal of Ecology 76:938-958.

SHAPIRO, S. S. \& WILK, M. B. 1965. An analysis of variance test for normality (complete samples). Biometrika 52:591-611.

SLIK, J. W. F., BERNARD, C. S., VAN BEEK, M., BREMAN, F. C. \& EICHHORN, K. A. O. 2008. Tree diversity, composition, forest structure and aboveground biomass dynamics after single and repeated fire in a Bornean rain forest. Oecologia 158:579-588.

SLIK, J. W. F., BREMAN, F. C., BERNARD, C., VAN BEEK, M., CANNON, C. H., EICHHORN, K. A. O. \& SIDIYASA, K. 2010. Fire as a selective force in a Bornean tropical everwet forest. Oecologia 164:841-849.

SNEDECOR, G. W. \& COCHRAN, W. G. 1989. Statistical methods. (Eighth edition). Iowa State University Press, Ames, Iowa. 491 pp.

UHL, C., CLARK, K., CLARK, H. \& MURPHY, P. 1981. Early plant succession after cutting and burning in the upper Rio Negro region of the Amazon Basin. Journal of Ecology 69:631-649.

XAUD, M. 1998. Avaliação de dados TM/LANDSAT e SAR/JERS na caracterização da cobertura vegetal e distribuição de fitomassa em áreas de contato floresta/savana no Estado de Roraima. Instituto Nacional de Pesquisas Espaciais, São José dos Campos. 151 pp.

YANG, C., RANDERSON, J.T., MORTON, D. C., DEFRIES, R. S., COLLATZ, G. J., KASIBHATLA, P. S., GIGLIO, L., YUFANG, J. \& MARLIER, M. E. 2011. Forecasting fire season severity in South America using sea surface temperature anomalies. Science 334:787-791.

ZARIN, D. J., DAVIDSON, E. A., BRONDÍZIO, E., VIEIRA, I. C. G., SA, T., FELDPAUSCH, T., SCHUUR, E. A., MESQUITA, R., MORAN, E., DELAMONICA, P., DUCEY, M. J., HURTT, G. C., SALIMON, C. \& DENICH, M. 2005. Legacy of fire slows carbon accumulation in Amazonian forest regrowth. Frontiers in Ecology and the Environment 3:365-369. 
Appendix 1. Summarized floristic statistics for fire disturbance classes (UF $=$ unburned forest; $\mathrm{BF} 1 \mathrm{~L}=$ once lightly burned forest; $\mathrm{BF} 1 \mathrm{H}=$ once heavily burned forest; $\mathrm{BF} 2=$ twice-burned forest and BF $3=$ thrice-burned forest) in northern Brazilian Amazon; Dens. = density of the listed species (ind. $\mathrm{ha}^{-1}$ ); $\mathrm{dbh}=$ species diameter at breast height (mean $\pm \mathrm{SD}$ ); IVI = importance value index (\%) of species considering only tree species. An asterisk $\left({ }^{*}\right)$ indicates the pioneer species.

\begin{tabular}{|c|c|c|c|c|c|}
\hline Class & $\begin{array}{c}\text { Species with highest } \\
\text { contribution to AGB (\%) }\end{array}$ & $\begin{array}{c}\text { Dens. } \\
\text { (ind. ha }{ }^{-1} \text { ) }\end{array}$ & $\begin{array}{l}\mathrm{dbh} \\
(\mathrm{cm})\end{array}$ & $\begin{array}{l}\text { IVI } \\
(\%)\end{array}$ & $\begin{array}{c}\text { Families with highest } \\
\text { contribution to AGB (\%) }\end{array}$ \\
\hline \multirow{5}{*}{$\overline{\mathrm{UF}}$} & Dinizia excelsa (15) & 2 & $94 \pm 73$ & 4.4 & Leguminosae (32) \\
\hline & Protium sp. (9) & 14 & $40 \pm 17$ & 5.7 & Sapotaceae (13) \\
\hline & Pouteria sp. 2 (9) & 5 & $56 \pm 21$ & 3.6 & Burseraceae (12) \\
\hline & Qualea paraensis (6) & 12 & $27 \pm 20$ & 3.5 & Vochysiaceae (8) \\
\hline & Sclerolobium sp.* (4) & 7 & $30 \pm 19$ & 2.5 & Lecythidaceae (5) \\
\hline \multirow{5}{*}{ BF1L } & Vochysia sp. (17) & 38 & $27 \pm 14$ & 9.3 & Vochysiaceae (22) \\
\hline & Manilkara huberi (10) & 9 & $43 \pm 16$ & 4.2 & Leguminosae (19) \\
\hline & Protium sp. (6) & 10 & $36 \pm 14$ & 3.8 & Sapotaceae (15) \\
\hline & Vitex sp.* (5) & 12 & $29 \pm 15$ & 3.3 & Burseraceae (13) \\
\hline & Protium sp. (4) & 21 & $20 \pm 10$ & 4.7 & Lamiaceae (5) \\
\hline \multirow[t]{5}{*}{$\mathrm{BF} 1 \mathrm{H}$} & Dinizia excelsa (16) & 2 & $86 \pm 19$ & 4.1 & Leguminosae (26) \\
\hline & Geissospermum sericeum (12) & 27 & $30 \pm 10$ & 8.3 & Apocynaceae (16) \\
\hline & Cecropia leucocoma* $(7)$ & 110 & $16 \pm 4$ & 18.2 & Sapotaceae (9) \\
\hline & Pouteria sp. (5) & 12 & $22 \pm 14$ & 3.8 & Burseraceae (9) \\
\hline & Protium sp. (5) & 4 & $38 \pm 19$ & 2.6 & Urticaceae (8) \\
\hline \multirow[t]{5}{*}{$\mathrm{BF} 2$} & Talisia sp. (8) & 6 & $37 \pm 24$ & 3.5 & Leguminosae (14) \\
\hline & Cecropia leucocoma * (8) & 137 & $15 \pm 4$ & 21.1 & Sapotaceae (13) \\
\hline & Pouteria sp. (7) & 18 & $23 \pm 11$ & 5.3 & Burseraceae (10) \\
\hline & Protium sp. (6) & 5 & $41 \pm 15$ & 3.1 & Urticaceae (8) \\
\hline & Spondias mombin (5) & 3 & $35 \pm 30$ & 1.8 & Sapindaceae (8) \\
\hline \multirow[t]{5}{*}{ BF3 } & Cecropia leucocoma * (13) & 95 & $18 \pm 5$ & 22.8 & Sapotaceae (16) \\
\hline & Pouteria sp. (11) & 20 & $24 \pm 11$ & 7.9 & Urticaceae (14) \\
\hline & Talisia sp. (9) & 8 & $30 \pm 13$ & 4.2 & Sapindaceae (9) \\
\hline & Jacaranda copaia* $(6)$ & 2 & $45 \pm 30$ & 2.0 & Lamiaceae (9) \\
\hline & Vitex sp.* (4) & 9 & $24 \pm 11$ & 3.9 & Lecythidaceae (7) \\
\hline
\end{tabular}

